DOI: 10.25178/nit.2017.1.2

\section{ОСОБЕННОСТИ ИСТОРИИ УСИНСКИХ ТУВИНЦЕВ}

\author{
Владимир Г. Дацышен \\ Сибирский федеральный \\ университет
}

\section{ASPECTS OF HISTORY OF THE USINSK TUVANS}

На территории Красноярского края России, в долине $p$. Ус, на границе в Республикой Тыва, до настоящего времени проживает особая тувинская общность - усинские тувинцы. Статья посвящена их истории и основывается на документах архивов Красноярского края, Минусинска, Иркутской области, Республики тыва.

Науке хорошо известны тувинцы Монголии и Китая. Усинские тувинцы же практически не изучались и не включались в число коренных народов Красноярского края. Лишь в последние 5 лет появились работы ученых Сибирского федерального и Тувинского госуниверситетов по этносоциальным и языковым особенностям усинских тувинцев.

Есть две версии истории заселения тувинцами Усинского района: 1) предки тувинцы кочевали в долине Уса, и этот район входил в территориальную область завершающего этапа тувинского этногенеза после XVII в.; 2) заселение тувинцами долины началось почти одновременно с появлением первых русских переселенцев. Можно предположить, что современный этап тувинского освоения Усинской долины начался в XVIII в., после окончательного закрепления этой территории за Россией и после оформления в Китайской империи административного образования Урянхай.

\author{
Vladimir G. Datsyshen \\ Siberian Federal \\ University
}

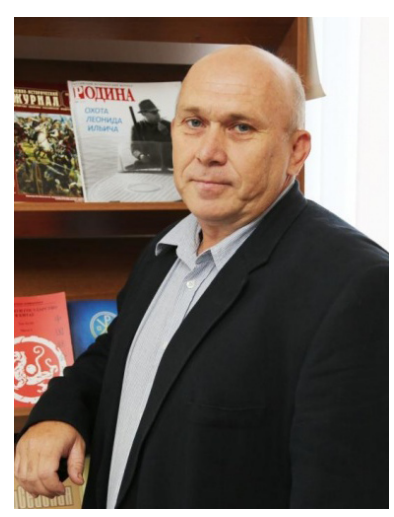

In the valley of the Us river, in the borderlands between Krasnoyarskii Krai and the Republic of Tuva, lives a community of the so-called Usinsk Tuvans. The article examines the history of this sub-ethnicity as it is shown in the documents preserved at the archives of Krasnoyarskii Krai, Minusinsk, Irkutsk Oblast and the Republic of Tuva.

Unlike the Tuvans living in Mongolia and China, Usinsk Tuvans have received almost no scholarly attention and have not been listed among the indigenous minorities of Krasnoyarskii Krai. It was only in the last 5 years that they have been for the first time studied by the researchers from Siberian Federal and Tuvan State Universities, with a special focus on ethnosocial and linguistic peculiarities of the Usinsk Tuvans.

Two versions of how the Tuvan population arrived in the contemporary Usinsk rayon are known to exist. According to the first, the nomadic ancestors of the Tuvans roamed the Us valley, and since the 17th century, this area has witnessed the final stage of Tuvan ethnogenesis. The second version maintains that the Tuvans arrived in the area almost at the same time as the first Russian settlers. It can be suggested that the contemporary stage of settling in the Us valley began in the 18th century when Russia's hold on the area was formalized by a treaty with

Дацышен Владимир Григорьевич - доктор исторических наук, профессор, заведующий кафедрой всеобщей истории Гуманитарного института Сибирского федерального университета. Адрес: 660041, Россия, г. Красноярск, пр. Свободный, 82, ауд. А-444. Тел.: +7 (391) 2-06-26-77. Эл. адрес: dazishen@mail.ru

Datsyshen Vladimir Grigorievich, Doctor of History, Professor and Chair, Department of general history, Institute of the Humanities, Siberian Federal University. Postal address: Office A-444, 82 Svobodny Ave., 660041 Krasnoyarsk, Russian Federation. Tel.: +7 (391) 2-06-26-77. Email: dazishen@mail.ru 
Активное русское освоение Усинского района началось в XIX в. Это привело к изменениям в тувинском освоении этой территории, например, тувинские власти в 1860-х г2. пытались создать препятствия русской земледельческой колонизации. Стали сокращаться тувинские кочевья, развивается хозяйственная кооперация и рост зависимости тувинцев от русских предпринимателей и крестьян. Тем не менее, на рубеже $X I X-X X$ вв. тувинское население округа оставалось многочисленным. Росли русско-тувинские противоречия.

Принятие Тувы под политическое покровительство России в 1914 г. вызвало и вопрос об организации усинских тувинцев. Они полностью сохраняли все атрибуты подданства цинскому императору. Наличие постоянного тувинского населения на соседней территории обусловило территориальные претензии Тувинской Народной республики. Вопрос о присоединении Усинского района к Туве сохранял остроту несколько первых десятилетий XX в.

$B$ целом, с момента пограничного русскокитайского размежевания в первой половине XVIII в. и до вхождения Тувы в состав России в 1944 2. постоянно проживавшие в Усинском районе тувинцы русской властью воспринимались в качестве иностранцеев. Лишь с 1950-х г2. в делопроизводственных документах местного сельсовета отражается местное тувинское население. Между тувинцами Тувы и Усинского района сохранялись активные миграционные процессы, но усинские тувинцы всегда имели этнокультурную специфику, которая формировалась фактом их проживания за пределами национального государственного образования $и$ тесным взаимодействием с русским населением.

Ключевые слова: тувинцы; усинские тувинцы; этническая история; приграничный район; Красноярский край; река Ус; Усинский район
China, and the Chinese empire, in its turn, set up the administrative unit of Uriankhai.

In the 19th century, Russians started to actively settle in what now is known as Usinsk rayon, which led to a change in Tuvan settlement of the same territory. In the 1860s, for instance, Tuvan leaders tried to prevent Russian agricultural colonization of the area. Nevertheless, nomadic camping grounds grew smaller, and agricultural cooperation began, which made Tuvans increasingly dependent on Russian traders and farmers. However, at the turn of the 20th century the Tuvan population of the area was still small, and the tension between Russians and Tuvans grew high.

When Tuva became a political protectorate of Russia in 1914, the issue of administrative status of Usinsk Tuvans came to a head. With Tuvans preserving the subjecthood of the Qing empire, their presence in the adjacent area gave rise to the territorial claims of the People's Republic of Tuva. The issue of possible cession of Usinsk rayon to Tuva had remained urgent for several decades in early 20th century.

Overall, from the Russian-Chinese border delineation in the first half of the 18th century to Tuva's accession into the USSR in 1944, the Tuvans permanently residing in Usinsk rayon were viewed by Russian authorities as foreign subjects. They appeared in the documentation of local village councils as late as in 1950s. There have always been active migration between Usinsk rayon and the Republic of Tuva, but Usinsk Tuvans at the same time have remained ethnoculturally distinct, which was upheld by the fact of residing outside the national region and close contacts with the Russian population.

Keywords: Tuvans; Usinsk Tuvans; ethnic history; borderlands; Krasnoyarskii krai; Us river; Usinsk rayon

\section{Введение}

История тувинского народа на протяжении длительного времени вызывает неизменный интерес у отечественных и зарубежных исследователей. И это не случайно, обусловлено, как уникальными характеристиками собственно тувинского этноса, так и геополитическими особенностями региона проживания тувинцев. На стыке монгольской и тюрко-сибирской культур, на границе Российской и Китайской империй, в определенных природно-географических и административно-государственных границах сформировалась тувинская этнонациональная общность. Сохранение собственной государственности в форме отдельной республики в составе Российской Федерации обеспечивает дальнейшее развитие тувинского народа, в том числе и в части всестороннего изучения этой национальности. 
Ужена этапе становления тувинской этно-национальной общности еепредставители проживали за пределами тувинских административно-государственных границ. Такая ситуация обогащает историю тувинцев, делает ее более сложной и противоречивой. Не случайно, в последние годы история проживающих за пределами Тувы тувинцев вызывает заметный интерес у исследователей. Мы полагаем, что особый интерес могут вызвать проблемы истории тувинцев, проживавших в приграничных с Тувой районах российских регионах. На сегодня хорошо известно, что историческая судьба тувинцев в разных районах Южной Сибири различна. На Алтае мы можем, очевидно, констатировать, что все тувинские этно-племенные или этно-родовые группы вошли в состав «алтайцев». В Иркутской области и Республике Бурятия из состава в прошлом единой тувинской этно-национальной общности выделились два новых этноса. А на территории Красноярского края до настоящего времени сохраняется особая тувинская общность, называемая обычно «усинские тувинцы».

Настоящая статья посвящена истории усинских тувинцев и основывается на документах архивов Красноярского края, Минусинска, Иркутской области, Республики Тыва, как опубликованных в научных изданиях, так и не опубликованных.

\section{Историография вопроса}

На сегодняшний день наиболее известным исследователем «зарубежных тувинцев» является М. В. Монгуш, издавшая в 2010 г. в Японии фундаментальную монографию «Один народ: три судьбы. Тувинцы России, Монголии и Китая в сравнительном контексте» (Монгуш, 2010). Автор пишет о тувинцах: «сегодня они представляют собой этнос, состоящий из этнического ядра, сосредоточенного в Республике Тыва, и этнической периферии - компактных групп, отделенных от основной части и живущих дисперсно в Монголии и Китае» (там же: 11). В работе указывается нахождение в России двух этнических групп, отколовшихся от тувинского этноса, но нигде не упоминается о тувинцах, проживающих в России за пределами Тувы.

Другие известные тувинские исследователи ограничивают географию «зарубежных тувинцев» монгольскими территориями (Маннай-оол, 1995). Крупнейший исследователь истории русско-тувинских отношений Н. М. Моллеров выделяет «пограничный вопрос» в советско-тувинских отношениях, но не связывает его с тувинским населением на русской стороне границы (Моллеров, 2005).

Красноярское научное сообщество до недавнего времени вообще не проявляло интереса к усинским тувинцам, которые всегда проживали на территории региона, но никогда не включались в число коренных народов Красноярского края. 
В современной историографии важное место занимают исследования Ч. К. Ламажаа, в которыхподнимаются какобщиеметодологическиепроблемытувиноведения (Ламажаa, 2013), так и изучения тувинских диаспор в российских регионах (Ламажаa, 2011). На сегодняшний день актуальным остается вывод, сформулированный Ч. К. Ламажаа: «Тувинцы, живущие за пределами своей исторической родины, представляют собой интересный объект для исследований... Однако, более изученными с этой точки зрения являются тувинцы, проживающие в Китае и в Монголии. Общины в других регионах практически не рассматриваются научной мыслью» (там же: 248). Этот тезис актуален для усинских тувинцев, с той лишь поправкой, что в Усинском районе тувинцы находятся за пределами Тувы, но не за пределами своей родины. В обобщающей работе «История Тувы» лишь кратко отмечается «тувинская община проживала в пределах Усинского пограничного округа (сумон Хереме)» (История Тувы, 2007: 45).

Понятие «усинские тувинцы» стало устойчивым лишь в XX в., и указывает оно не только на район проживания, но и на специфику проживающих в этом районе тувинцев. Усинским районом называется территория бассейна реки Ус на юге Красноярского края.

Развитие этно-национальной группы за пределами национально-государственных границ осложняет этно-социальные и общественно-политические процессы. Делает более богатой и противоречивой историческую картину этноса. Комплексные исследования усинских тувинцев, проведенные силами кафедры всеобщей истории Гуманитарного института Сибирского федерального университета, при участии коллег-филологов, подтверждают гипотезу о существовании особой этно-культурной группы усинских тувинцев, отличающейся не только от соседних народов региона, но и от тувинцев Республики Тува (Дацышен, 2009: Электронный ресурс; Журавель, 2011ab; Фельде, Журавель, 2012; Кривоногов, Михайлова, 2014; Krivonogov, Mikhailova, 2015; Михайлова, 2014: Электр. ресурс). Эти данные подтверждаются и последними работами коллег Тувинского государственного университета (Сувандии, 2016; Куулар, 2016; Куулар, Сувандии, 2016; Соян, 2016).

Т. Н. Журавель приходит к следующим выводам: «в настоящем усинские тувинцы практически не ощущают связи со своей этнической родиной... очень часто приходилось слышать, что усинских тувинцев в Туве принимают плохо, называют их русскими» (Журавель, 2011b: Электр. ресурс).

Такая ситуация заставляет особое внимание уделить проблемам истории тувинцев в Усинском районе.

\section{Заселение тувинцами Усинского района}

Горная долина реки Ус в Саянах попала в сферу интересов Русского государства, в начале XVII в. Опубликованный военным исследователем А. М. Барано- 
вым в начале XX в. документ под названием «Выписка из расспросных речей, записанных в сибирском приказе со слов Тарского города атамана Василия Тюменца о посольстве в 1616 году к Мунгальскому царю Алтыну» указывает на то, что уже в 1616 г. русские посещали Усинский район.

Усинская долина была хорошо знакома русским задолго до оформления здесь государственной границы. В статейном списке посольства томского сына боярского Р. Старкова, ездившего к Алтын-хану Лубсану в 1665 г., говорилось: «И мы, Роман с товарыщи... с Уеку перешли на Ус-реку, и по Усу-реке шли две недели и вышли на Енисей-реку, и пошли по Енисею и Енисем шли промеж Саянским каменеем...» (Русско-монгольские ..., 1996: 188). В дневнике Д. Г. Мессершмидта сохранилась запись 1722 г., сделанная в расположенной недалеко от Караульного острога в деревне Медведево: «Наш хозяин и еще один житель из этой деревни не раз бывали в Монголии и Сойотии и много рассказывали нам о своих путешествиях... Эти люди сообщили нам также, что река Уса, берущая начало недалеко от Хамсары, является последней большой рекой, впадающей в Енисей в его верховьях» (Messerschmidt, 1961: 181-182) ${ }^{1}$. К. Риттер сообщал так же об информаторе у Мессершмидта - «калмыке с р. Уса» (Риттер, 2007: 124). Окончательное вхождение данной территории в состав России было оформлено Буринским трактатом 1727 г.

B XVII в. все предки тувинцев, не исключая и жителей Усинской долины, русскими властями считались русскими подданными. В Протоколе совещания под председательством Иркутского генерал-губернатора от 28 февраля 1911 г. говорилось, что в 1726 г. российский посланник Рагузинский получил в Красноярске, сведения, в том числе и о «сойотах (урянхах) живущих ниже реки Хемчика, по Енисею», которые, как и подавляюще большинство других тувинцев в то время платили дань России (Собрание архивных ..., 2014: 50).

Во время русско-китайского размежевания 1727 г. возникла противоречивая картина. Российский посланник С. Рагузинский и пограничный комиссар С. Колычев докладывали, что большая часть Усинской долины вошла в состав России, и большинство бывших ясачных жителей Саян остались за Россией. Правда, когда давались конкретные цифры, то картина была несколько иной. В апреле 1728 г. С. Рагузинский докладывал, что на монгольской стороне осталось 194 «однособольника урянха изменника» а на русской - 162 таковых из Монголии (Русско-китайские ..., 2006: 233). «В красноярских ведомостях за рукою подполковника и красноярского воеводы Григория Колюбакина декабря 31 дня 727 году» утвеждается: «В Шараданове улусе 6 человек, взято с них ясаку на 726 год 6 соболей. Кочуют они за Саянским камнем на реке Уске. Оные иноземцы кочуют на реке Уск, а та река Уск за границею в Монгольской землице. В Аскачинском

${ }^{1}$ С изданием и текстом перевода автор знакомился в личном архиве И. Т. Лалетина. 
улусе 11 человек, с них взято ясаку на 726 год 20 соболей, кочуют они за Санским камнем по рекам Кемчюке, на Уске, на Карабурине и в Енисейских россохах...» (там же: 272).

На сегодняшний день остаются две версии истории заселения тувинцами Усинского района.

Много аргументов в пользу того, что предки тувинцы кочевали в долине Уса, и этот район входил в территориальную область завершающего этапа тувинского этногенеза после «смутного времени» XVII века. В знаменитой работе К.Риттера «Землеведение Азии» об Усинской долине сообщается: «Вся их речная область принадлежит России по трактатам, но сибирское начальство ничего не знало о ней до Пестерева, а исследование ее было затрудняемо перекочевкою сюда подданных Китаю пограничных племен» (Риттер, 2007: 123-124). К. Риттер писал, что пограничный комиссар Пестерев в 1770-х гг. встречал на притоке Уса - Иджиме, «сойотские племена Байгарин и Матар» и даже «китайского мандарина с красным шариком на шапочке». В работе известного исследователя Ф.Я. Кона говорится: «Лет 25 тому назад, - пишет в 1886 г. вновь назначенный Пограничный начальник, - на том месте, где ныне расположены усинские деревни, кочевали богатые роды сойот-урянх, но с появлением первых переселенцев-староверов урянхи стали постепенно откочевывать из этих мест... Небольшие кочевья их остались еще вниз по берегам р. Уса в малодоступных местностях...» (Кон, 1914: 45).

Согласно другой версии, заселение тувинцами Усинской долины началось почти одновременно с появлением первых русских переселенцев. В работе первого Енисейского губернатора А. П. Степанова дается подробное описание встречи пограничных казаков с тувинскими делегациями, но не упоминается о тувинском населении в Усинском районе (Степанов, 1997). Исследователь Тувы инженер В. М. Родевич в начале XX в. утверждал, что долину Уса тувинцы засели лишь в середине XIX в. Он писал: «русские широко открыли урянхам свою границу приблизительно с 1840 г., и те заселились по Енисею. Кочуя в горах от Кемчика до Уса, и кое-где по Усу; не теряя связи со своими хошунами и сумо, они платят дань Китаю. Сойоты-охотники, кочующие в пределах Урянхая, так же ежегодно уходят промышлять зверя в Русские Саяны... Откочевывают из Урянхая на Саянский хребет и сойоты-оленеводы и скотоводы в поисках хороших летних пастбищ» (Родевич, 2007: 378). В пользу последней версии можно привести и следующие факты. В документах, направляемых от тувинских нойонов на имя Усинского пограничного начальника, с указанием административного устройства и районов проживания тувинцев, не упоминалась Усинская долина (Собрание архивных ..., 2014: 94).

Суммируя разные известия и точки зрения, можно предположить, что современный этап тувинского освоения Усинской долины начался в XVIII в., после, с одной стороны, окончательного закрепления этой территории за Росси- 
ей, и с другой стороны - после оформления в Китайской империи тувинского государственно-административного образования Танну-Тува Урянхай под властью тувинского амбын-нояна. Тувинское освоение района не носило комплексный характер, здесь преобладали сезонные кочевья и охотничий промысел, никаких указаний на тувинское земледелие в XVIII-XIX вв. не сохранилось. Для опровержения или подтверждения версии об активизации освоения Усинской долины тувинцами именно в $1840-\mathrm{x}$ гг. необходимо провести дополнительные исследования. Особо следует отметить, что Усинскую долину осваивали тувинцы из сумо, не подчинявшихся тувинскому амбын-нойону, а находившихся в ведении монгольских князей.

В данный период имело место и хозяйственное освоение Усинской долины шушенскими крестьянами, скрывавшими это от русских властей. Кроме того, Усинская долина регулярно посещалась енисейскими казаками, выезжавшими в верховья Иджима для проверки пограничных знаков и меновой торговли с тувинцами. Исследователя Л. Э. Шварца в путешествие по Усинской долине в 1858г. сопровождал казак, «делавший уже 15 раз подобное путешествие», а так же шушенский крестьянин. Л. Э. Шварц здесь отмечал «ни казаки, ни крестьяне не считают Ус за пограничную реку с Китаем», утверждая: «Усинская степь обетованная земля крестьян Шушинского села» (Шварц, 2007: 52). Исследователь Л.Э. Шварц в 1858 г. утверждал, что прежде шушенские крестьяне обращались за разрешением переселиться в Усинскую долину, но российские власти неизменно отказывались выдать крестьянам такое разрешение. Очевидно, материалы экспедиции 1858 г. опровергают распространенную версию о появлении старообрядческих поселков на Усе в первой половине XIX в.

Представление об усинских тувинцах дают материалы экспедиции ИРГО 1858г. Начальник экспедиции Математического отдела Сибирской экспедиции ИРГО Л.Э. Шварц отметил: «сойоты не считают Ус пограничной рекой, хотя фактически они владеют им» (там же), он так же увидел, что: «в долине Уса и Иджима сойотское население очень многочисленно» (там же: 54). Остановившись в долине Иджима начальник экспедиции зафиксировал: «В полдень к нам зашел зайсан-старшина с четырьмя спутниками из верхнего улуса, находящегося от нас почти в верстах расстояния... Я успел только узнать, что старший зайсан - наш гость был младший - отправился десять дней тому назад в Улясутай с ясаком» (там же: 54). Л. Э. Шварц так же описал два тувинских поселения на Иджиме: «За озерами расположен улус, образуя около них большую дугу; дома в нем весьма разнообразны» (там же); «скоро мы пришли к нижнему улусу, состоящему из четырех бедных юрт, которые едва моли дать убежище от дождя. Немного скота большей частью телят (большой скот был в горах) - паслось возле улуса; тут же бродило несколько лошадей» (там же: 55). На берегу Уса Л. Э. Шварц также встречал тувинцев, он писал: «подле нас стояли три сойотские юрты, в которых жили четверо мужчин, двое женщин и большое число взрослых и малолетних детей» 
(там же: 56). Спускаясь по Усу в Енисей, начальник экспедиции отмечал: «Очень часто нам случалось плыть мимо юрт, и во время ночных остановок нас часто посещали сойоты» (там же: 61). В материалах экспедиции так же отмечается, что жившему на Иджиме зайсану подчинены все тувинцы в Усинском районе, «у которого в распоряжении находится вообще более 70 человек» (там же: 58).

\section{Усинские тувинцы в XIX веке}

Активное русское освоение Усинского района началось в XIX в. Сначала в бассейне Уса и прилегающих районах начинается добыча золота, затем здесь появляются русские торговцы. Затем, как отмечалось в документах: «В 1863 году в Южную часть Минусинского округа Енисейской губернии явились неизвестные люди в числе 79 душ мужчин и 66 душ женщин, которые без разрешения устроили селения на казенных землях...» (Государственный архив Красноярского края - ГАКК. Ф. 595, оп. 19, д. 299, л. 1). Именно за старообрядцами, основавшими Усинск, в 1860-х гг. были закреплены казенные земли в Усинской долине. B XIX в. приграничные с Тувой русские земли в бассейне Енисея вошли в состав Минусинского округа Енисейской губернии. С введением закона 1882 г. о преобразовании общественного управления государственных крестьян Восточной Сибири из селений Верхне-Усинского и Нижне-Усинского было образовано отдельное сельское общество и открыт сельский суд. 30 декабря 1885 г. последовало высочайшее повеление об образовании Усинского пограничного округа.

Первый Усинский пограничный начальник А. М. Африканов внес большой вклад в изучение усинских тувинцев. В его работе «Русская торговля в Урянхайской земле» говорится: «Кочевья урянхов некоторых сумо Бейса и да-хошунов перемешаны... сумо: Ада-Тюлюш - по правому берегу Улу-кхема по рр. Темерсуку и Ичжиму, а рядом с ними Киргиз, - по рр. Кули-кхему, Орта-Кхему и в пределах Усинского округа по Енисею, ниже Бом-Кемчика по рр. Б. и М. Урам, Юргоне, Оспану и даже Атысу, впадающему в р. Золотую... Другой княжеский Да-хошун находится в ведомстве Хоту-гоиту Цзасакту-хана хошуна Бичирилты и в нем тоже насчитывается до 17 сумо, из коих по сю сторону Танну кочуют лишь два сумо: 1) Мады - в верховьях р. Уса, по рр. Уту, Одже и Уюку и 2) Джлда - по р. Тапсе; сумо эти малочисленны по составу» (Африканов, 1890: 51). Но в официальных отчетах пограничного начальника А. М. Африканова представлена противоречивая картина. В 1886 г. он утверждал, что: «Небольшие кочевья их оставались еще вниз по берегам Уса в малодоступных местностях» (ГАКК. Ф. 49, оп. 1, д. 394, л. 2). В отчете за 1887 г. говорилось: «В Усинском округе постоянных кочевьев урянхов почти нет, если не считать два-три улуса урянхов, расположенных на займищах по берегам Енисея между 23 пограничным знаком и устьем Уса...» (ГАКК. Ф. 595, оп. 19, д. 3773, л. 5об.). Однако, в 1889 г. Усинский пограничный начальник писал Иркутскому генерал-губернатору: «составил списки китайских подданных Урянхов, проживающих в местностях, принадлежность 
которых России не подлежит сомнению... проживающих на нашей территории более ста урянхайских семейств имеют стада и полное хозяйство и даже, частию, занимаются хлебопашеством (по реке Юргуни)» (Государственный архив новейшей истории Иркутской области - ГАИО. Ф. 25, оп. 11, д. 148, л. 1).

В документах Усинского пограничного округа не встречается выделения усинских тувинцев в качестве отдельной группы. Например, в «Инструкции Усинскому Пограничному Начальнику по возложенной на него Высочайше утвержденным 30 декабря 1885 г. мнением Государственного Совета обязанности ведения пограничных сношений» говорится лишь о двух категориях населения в регионе - «русских и Урянхов», безразлично места их проживания - в российском Усинском пограничном округе или китайском Урянхайском крае (ГАКК. Ф. 595, оп. 48, д. 771). Но здесь можно указать, что еще Л. Э. Шварц в 1858 г. отметить, что встреченные им на Усе тувинцы «были каким-то образом трезвы и оказали нам более доверия, чем их земляки на Иджиме» (Шварц, 2007: 56). В материалах А.М.Африканова есть указания на заимствование усинскими тувинцами элементов русской культуры. Например, в 1887 г. он отмечал, что тувинцы, побывавшие в Усинских селениях, стали носить бродни ${ }^{1}$ (ГАКК. Ф. 217, оп. 2, д. 70, л. 40).

Ясной и полной картины тувинского населения Усинского района русские власти не имели. В составленном в конце XIX в. «Алфавитном списке инородческих племен и народностей, проживающих в Енисейской губернии», дается следующая информация: «Урянхайцы - кочевой народ, монгольского племени. Главные занятия их скотоводство и звероловство, хлебопашество в младенческом состоянии. Урянхайцы назывались также Калмыками двоеданцами, потому, что до 1865 г. они считались подданными, как русскими, так и китайцами и вследствие этого платили большую дань. Урянхайцы отчасти православные, отчасти язычники буддисты. - Территория: Юго-западная часть Бийского округа Томской Губернии и Юго-западная часть Минусинского Округа Енисейской Губернии; встречаются в Байкальских горах. Численность по сведениям за 1865г. - 15000. По местным сведениям, в Минусинском округе урянхайцы не показаны вовсе. В Усинском округе проживают «Урянхи», китайские подданные, в самом незначительном количестве...» (ГАКК. Ф. 31, оп. 1, д. 208, л. 29). Русские власти не пытались поставить под свой контроль усинских тувинцев. Наоборот они не препятствовали тому, что бы в усинских селениях находился цинский чиновник, управлявший всеми тувинцами (ГАКК. Ф. 595, оп. 19, д. 3773, л. 6об.).

Русское комплексное освоение Усинского района привело к изменениям в тувинском освоении этой территории. В документах сохранились косвенные указания на то, что тувинские власти в 1860-х гг. пытались создать препятствия

\footnotetext{
${ }^{1}$ Бродни - традиционная сибирская мужская кожаная обувь на мягкой подошве с высокими голенищами.
} 
русской земледельческой колонизации. В материалах Минусинского окружного исправника есть такие сообщения: «... усматривая из Указа Енисейской Казенной Палаты от 13 октября 1866 года №5394, что вследствие ходатайства предместника моего Г. Третьякова о прекращении стеснений со стороны Китайского Начальства Русских крестьян на Усинской местности, в дозволении ими пользоваться пашнями и другими угодьями на 50 верст не далее реки Уса по распоряжению Г. Начальника Губернии Казенною Палатою требовалось от Губернского Землемера указание границы Минусинского округа от Китайских владений...» (Архив города Минусинска - АГМ. Ф. 39, оп. 1, д. 5, л. 70-70 об.). Тем не менее, цинские власти в 1860-х гг. добились выселения русских с долины реки Уюк, но даже не поднимали вопроса о русских, живших на Усе.

Во второй половине XIX в., вероятно, сокращаются тувинские кочевья, развивается хозяйственная кооперация и рост зависимости тувинцев от русских предпринимателей и крестьян. В конце XIX - начале XX в. приграничные районы России оставались традиционным местом промыслов цинских подданных тувинцев. В отчете А. М. Африканова за 1887 г. говорилось: «Помимо сойот, проживающих в Усинском округе для заработков личным трудом, много сойот уходят в Саяны для охоты на пушного зверя» (ГАКК. Ф. 595, оп. 19, д. 3773, л. 6об.). Описание тувинцев в Усинском районе в конце XIX в. дано в работе В.А.Ошуркова «Из странствий по земле Урянхов»: «На прииске есть рабочие и из сойот... Кругом приисковых построек, на склонах соседних увалов... виднеются конические юрты кочевников. Тут же пасутся небольшие стада рогатого скота и овец. Целое лето сойоты гонят водку из молока и тем причиняют большую тревогу приисковой администрации... Помимо водки и заработков, близость сойотских юрт объясняется еще и той ролью, какую сойотские женщины играют по отношению к приисковому люду, а сверх того, сойотам и деваться-то некуда: вершины речек представляют прекрасные летние пастбища, где нет ни комара, ни мошек» (Родевич, 2007: 378). Современники отметили своеобразную форму эксплуатации тувинцев-промысловиков переселенцами-хакасами: «Засельщики “Усть-Усинского" поселка, войдя в тесное общение с сойотами соседями скоро усвоили себе выгодность снаряжения на промысел вместо себя сойота: давая ему охотничьи припасы и продовольствие, хозяин-промышленник получает с охотника-сойота две трети добытого» (Лавров, 1920: 21). Тувинцы приходили к русским на сезонные заработки, например на сенокос. Кроме того, тувинские работники вместе с женами и детьми стали селиться в русских селениях, чаще в качестве работников у местных крестьян.

K концу XIX в. тувинское население Усинского округа оставалось многочисленным. В 1889 г. усинский пограничный начальник писал Иркутскому генералгубернатору: «составил списки китайских подданных Урянхов... на каждого русского поселившегося на китайской земле причитается 10урянхов, поселившихся У нас» (ГАИО. Ф. 25, оп. 11, д. 148, л. 1). В начале XX в. на территории Усинского 
района сохранились тувинские кочевья, в основном в верховьях Уса, местные тувинцы занимались охотничьим промыслом, в низовьях Усы сохранялось тувинское земледелие, много тувинцев были временными или постоянными работниками у усинских крестьян.

\section{Усинские тувинцы и русские}

Русское торговое, горнопромышленное и земледельческое освоение Усинской долины и прилегающих территорий Тувы привело к росту русско-тувинских противоречий. Современники отмечали, что в середине XIX в. «Кочующие в долине Уса сойоты встретили первых русских весьма недружелюбно и позволяли себе насилия над их имуществом и личностью, угоняли скот и привязывали их раздетыми до-нага к деревьям...» (АГМ. Ф. 71, оп. 2, д. 51, л. 196об.). Красноярский кафедральный протоиерей в. Д. Касьянов в июле 1878 г. записал в своем дневнике: «На Усу золото. Соёты поколотили русских - минусинских за их обиды и неправды» (Касьянов, 2012: 189). Для предотвращения русско-тувинских конфликтов Петербург предписывал, чтобы местные русские власти шли тувинцам на уступки (ГАКК. Ф. 595, оп. 8, д. 5446, л. 1). В «Докладе заведующего Пограничными делами Усинского округа Иркутскому генерал-губернатору о принятии Тувы под покровительство России от 24 августа 1914 г.» дается картина серьезных проблем в отношениях между русскими и тувинцами, кочевавшими в Усинской долине и прилегающих районах Тувы. А. Церерин писал о «урянхах Маады и Чооду сумонов, в конец разоренных монголами и отчасти русскими» следующее: «Урянхи этих сумонов почти поголовно воры и от них жестоко страдает русское население» ...»(Собрание архивных ..., 2014: 163).

Принятие Тувы под политическое покровительство России вызвало и вопрос об организации усинских тувинцев. Правда, в 1914 г. как и прежде, усинские тувинцы состояли в сумо, управления которых находились на территории ТаннуТува Урянхая, а подчинялись монгольским князьям. В «Докладе заведующего Пограничными делами Усинского округа Иркутскому генерал-губернатору о принятии Тувы под покровительство России от 24 августа 1914 г.» говорилось: «Высочайшее повеление о принятии урянхов под покровительство России относилось лишь к урянхам “пяти хошунов”, между тем в Урянхайском крае, помимо пяти хошунов, кочуют еще два отдельных незначительных сумона Маады и Чооду, численностью в обоих сумонах около 1000 душ, кочевья которых начинаются недалеко от села Усинского. Из этих сумонов-данников монгольского князя вана Намхайчжанцана, я также еще в минувшем году удалил монгольских чиновников и предполагал присоединить население сумонов, в виду незначительности такового, к управлению амбын-нойона. Но собравшиеся чиновники и население в самой категорической форме высказалось против этого и попросили меня устроить для них отдельное управление, что и было мною сделано. Так 
как кочевья у этих сумонов общие, то во главе управления был мною поставлен «тэригун-цзайсан» - главный цзайсан с двумя помощниками...» (Собрание архивных ..., 2014: 162-163).

Проживание тувинцев в пределах России обусловило проблему православной миссионерской деятельности среди этой части «русских иностранцев». В июле 1878 г. епископ Енисейский и Красноярский писал Енисейскому губернатору: «Находящийся в Усинском крае Минусинского округа, среди раскольников и Сойот в качестве миссионера, Николай Путилов, в донесении своем... пишет, что когда весною сего года приехал на р. Ус для исполнения духовных треб Священник села Субботина Гавриил Силин, то к нему явился один Сойот и изъявил желание креститься вместе со своим семейством» (ГАКК. Ф. 595, оп.1, д. 5730, л. 1). Сам миссионер Н. А. Путилов писал: «...когда этот край заселится православными, а сойоты примут христианство, то эта страна процветет и будет иметь влияние на всю Енисейскую губернию» (Путилов, 1914, № 1: 32). Миссионер-доброволец представил руководству Енисейской епархии свой план миссионерской работы и даже попытался добиться выделения специального земельного фонда для «поселения на них крещеных соет» (Путилов, 1914, № 3-4: 92). В отчете за 1878 г. Н. А. Путилов писал: «Осенью приезжали на Ус двое именитых сойот (один зять нойона), которым я подарил две русских азбуки; они условились со мной о том, что весною, когда я возвращусь на Ус, они привезут своих детей учиться... Вообще, если бы сойоты учились здесь по-русски и приняли бы христианство, то это много способствовало бы сближению их с русскими, на которых стали бы смотреть не как на своих врагов (как теперь), а как на своих единоверцев...» (Путилов, 1914, № 5: 338-339). В декабре 1878 г. генерал-губернатор Восточной Сибири сообщал Енисейскому губернатору: «... Министерство Иностранных Дел не встречает препятствий к принятию соет в Православную веру, но, во избежание столкновений с китайскими властями, находит полезным допускать принятие их в лоно нашей церкви лишь отдельными лицами, а не целыми семьями и обществами... при принятии Соет в Православие должно соблюдать строгую разборчивость... причем желательно бы впредь заявлять им, что принятие ими Православия не дает им ни каких прав на наше покровительство и заступничество перед Китайскими властями» (ГАКК. Ф. 595, оп. 1, д. 5730, л. 7). 29 января 1879 г. усинский миссионер получил официальное разрешение крестить тувинцев, но ни одного случая крещения усинских тувинцев в это время, очевидно, не было.

В начале 1880-х гг. интерес к Усинской долине проявило руководство Енисейской епархии. Красноярский кафедральный протоиерей В. Д. Касьянов 8 января 1883 г. записал: «у Архиерея речи... об Усинской церкви и о Миссионерском обществе...» (Касьянов ..., 2012: 304). Через несколько дней, 16 января, он вновь отметил: «Вечером у архиерея заседание Миссионерского общества о том, ехать ли ему на Ус для освящения церкви» (там же: 305). В начале 1884 г. Усинскую до- 
лину посетил епископ Енисейский и Красноярский Исаакий. В первом номере «Енисейских Епархиальных Новостей» можно прочитать: «В 25 день Января сего года Его Преосвященство, Преосвященнейший Исаакий, Епископ Енисейский и Красноярский, выехал в Усинский край (к Китайской границе), по делам миссии и для обозрения церквей» (Енисейские ..., 1884: 8). В дневнике протоиерея Касьянова записано: «25 января, среда. Около 7 часов утра отвалил Преосвященный по Енисею на Ус в 2-х экипажах... 16 февраля... От Означеной до Усу - 280 верст, езда по Енисею, утесах много полыней, есть Федосова яма, где Федосий (протоиерей-подвижник на Усу), протоиерей, подвизался. Весь кортеж или поезд состоял из 17 экипажей, по одной лошади и седоку, у Архиерея 2 лошади. Освящение церкви...» (Касьянов ..., 2012: 338).

По результатам поездки на Ус Епископ Исаакий писал: «Те из Сойот, которые давно живут около христиан, знают некоторые христианские молитвы и, если не принимают св. Крещения, то из боязни подвергнуться преследованию со стороны своего духовенства по таким причинам, которые нельзя признать серьезными... Надо полагать, что усердный, преданный своему делу миссионер без особых трудов может приобрести новых чад для Св. Церкви в среде Сойот язычников» (ГАКК. Ф. 674, оп. 1, д. 7847, л. 13). Исаакий выступил с ходатайством направить в Верхне-Усинское особый миссионерский причт, указывая: «К обязанностям причта должно быть отнесено прежде всего попечение о православных чадах Св. Церкви, в особенности о крещеных инородцах; затем причт должен иметь в виду старообрядцев и Сойот язычников, проживающих в Усинском крае» (ГАКК. Ф. 674, оп. 1, д. 7847, л. 13об-14).

Первым священником Николаевской церкви в Верхне-Усинске стал миссионер Платон Тыжнов, служивший до 1884 г. настоятелем Шушенской церкви. В дневнике кафедрального протоиерея Касьянова за 2 февраля 1885 г. записано: «Священник Платон Тыжнов из Ермаковского села приехал на Ус на 7-й день, с 14 сентября до 20 числа ехали верхом... всего было 5 лошадей. Был снег, горы: Куломыс и Арадан, на последний можно подняться с помощ лошади, держась за ея хвост» (Касьянов ..., 2012: 372). В отчетном докладе священника ВерхнеУсинской Миссионерской Николаевской церкви Платона Тыжнова благочинному о проделанной в 1884 г. работе о крещении тувинцев не упоминались. В документе говорилось: «Некоторым из обрусевших Сайотам я предлагал креститься и обучить молитвам, но они не соглашаются по той причине, что их начальники и ламы воспрещают им не только креститься, но и носить русскую одежду» (АГМ. Ф. 17, оп. 1, д. 264, л. 41об).

Несмотря на разные проблемы, усинский священник все же находил возможности крестить тувинцев. В документах говорится: «1888 году просвещен Св. Крещением Священником Усинской миссионерской Церкви О. Платоном Тыжновым» «Подданный Китайской Империи из племени Урянхайцев, Сумы БижиКожун, Калгадчика, и его Св. Крещению Ивана по восприемному отцу Тыжнова» 
(ГАКК. Ф. 595, оп. 1, д. 3343, л. 2-2об.). Но после принятия православия этот усинский тувинец уехал в Шушенское.

Длительное проживание усинских тувинцев по соседству с русскими и на территории российского пограничного округа не привело к принятию ими православия. В «Отчете Красноярского Епархиального Комитета Православного Миссионерского Общества за 1901 г.» говорилось, что село Верхне-Усинское находится «в ведении Миссионерского Комитета состоит потому, что в это село иногда заходят китайские подданные - язычники Сойоты; но миссия христианской проповеди по отношению к ним не имеет никаких плодов» (Енисейские епархиальные, 1902: 210). Собственно на территории Усинского пограничного округа православная миссия среди местных тувинцев не имела большого успеха во многом по политическим причинам. Тувинцев далеко не всегда крестили даже в случае таковых просьб за пределами Усинского округа. Весной 1908 г. священник Сабинской церкви сообщил епископу Енисейскому и Красноярскому: «китайский подданный из рода сойотов Дизоль». При этом он указал: «Дизоль говорит, что ему теперь нельзя показаться на свою родину, в Усинский край, потому остриг свою косу, что считается у них нарушением священного обычая, за что будет казнен своими родичами. Принимали его под свое покровительство австрийской иерархии старообрядцы, желая его присоединить к своей вере, но он это отвергнул, а желает присоединиться к Св. Православной Христианской церкви. Дизола я пока поручил одному грамотному прихожанину деревни Кальской, чтобы он научил бы его первоначальным молитвам впредь до разрешения епархиального начальства» (ГАКК. Ф. 674, оп. 1, д. 3174, л 1-1об.). Но епархиальное руководство уклонилось от решения данного вопроса. Консистория потребовала, чтобы Дизоль «исходатайствовал перед гражданским начальством документ, удостоверяющий его личность». Очевидно, этому тувинцу, как и многим другим, так не удалось принять православие.

Таким образом, проживавшие на территории Усинского пограничного округа тувинцы полностью сохраняли все атрибуты подданства цинскому императору. Все усинские тувинцы, крестившиеся, как Калгадчик (Иван Тыжнов) или просто принявшие русский образ жизни, как Дизол, вынуждены были покидать Усинскую долину и переезжать вглубь российской территории. При этом, тувинцы сталкивались с проблемой нежелания русских властей принимать их в русское подданство.

\section{Усинские тувинцы в начале ХХ века}

Наличие постоянного тувинского населения на соседней территории обусловило территориальные претензии тувинского национально-государственого образования. И это не случайно, так как строительство национального госу- 
дарства предполагало идею тождественности этнической и государственных территорий. Не случайно на протяжении нескольких первых десятилетий ХХ в. стоял вопрос о присоединении Усинского района к Туве. В 1920-х гг. в регионе вспоминали: «В результате падения престижа России после войны с Японией Танну-тувинский Огурды-Хайдуп, пользовавшийся большим влиянием в крае, самовольно передвинул государственную границу на север в русские владения и поручил поставленной им там страже не пропускать за Саяны русских транспортов и эмигрантов... Конфликт этот получил широкую огласку и вызвал посылку в край русского военного отряда в 125 человек. Хайдуп китайскими властями был отдан под суд, и дело его не имело серьезного последствия для Засаянского края» (Красноярский краевой краеведческий музей. Вспомогательный фонд (в/ф) 9463/8: 5). М. Г. Сафьянов утверждал: «Тувинцы до сих пор считают своей территорией не только весь Урянхай... но в состав земель ТаннуТува они относят так-называемый Усинский пограничный округ. Там, говорят они, где расположены сейчас усинские селения Минусинского округа, прежде их деды пасли скот, охотничали и пахали землю» (Кайский, 1926: 18-19).

Во время гражданской войны в Усинском районе имели место межнациональные конфликты. Именно в Усинском районе произошла одна из самых страшных трагедий в истории Гражданской войны в Засаянском крае. В сентябре 1919г. тувинская банда уничтожила русский поселок Гагуль, зверски убив всех его жителей, около 70 человек русских и хакасов. Но убийствами занимались банды из западной Тувы, фактов межнациональных столкновений между представителями разных общин, проживавших в Усинском район, не зафиксировано.

После окончательного установления советской власти на юге Сибири и оформления Тувинской республики проживавшие на Усу тувинцы остались под властью Тувы, а русские власти их не касались. Например, в планах работы Усинского Районного комитета ВКПб. на 1924 г. не было вопросов, связанных с тувинцами (ГАКК. Ф. П-44, оп. 1, д. 4). О тувинцах не упоминалось и в докладе «Усинская волость при новом адмделении Минусинского уезда Енисейской губернии» 1924 г. (ГАКК. Ф. Р-49, оп. 1, д. 475).В делопроизводственной документации по Усинскому району тувинцы фигурировали лишь в связи проблемами незаконного перехода границы и контрабанды. При этом в научно-справочной литературе численность тувинцев в долине Уса в 1920-х гг. определялась в 2,5 тыс. человек (Сойоты, 1929: 61).

Российское общество в Советской Сибири слабо себе представляли специфику населения Усинского района. В научно-справочном издании «Вся Сибирь» за 1925 г. говорилось: «тувинцы родственны с туземцами нашего Усинского края» (Вся Сибирь ..., 1925: 70). Кроме того, непризнание факта существования в составе населения Енисейской губернии такой группы как «усинские тувинцы» привело советское руководство к признанию территориальных претензий ТНР 
на Усинский район. В «Докладе Комиссии ЦКК об обследовании партийной и советской работы в Тувинской Народной Республике» от 23 сентября 1929 г., опубликованном в «Протокол заседания Сибкрайкома», говорилось: «Самым слабым местом в области дипломатической работы является пограничный вопрос. Тувинцы ставят вопрос так, что Усинский район принадлежит им... с Усинским же районом дело обстоит таким образом, что НКВД и Полпредство еще сами не привели этого вопроса себя в ясность. Они тянут в этом вопросе с тувинцами, они говорят тувинцам, что размежевание сейчас актуального значения не имеет» (ГАНИИО. Ф. 16, оп. 1, д. 951, л. 38).

\section{Заключение}

Таким образом, с момента пограничного русско-китайского размежевания в первой половине XVIII в. и до вхождения Тувы в состав Российской федерации в середине XX в. постоянно проживавшие в Усинском районе тувинцы русской властью воспринимались в качестве иностранцев. Лишь с 1950-х гг. в делопроизводственных документах местного сельсовета отражается местное тувинское население.

На протяжении всего рассматриваемого периода существовали не только тесные связи, но и активный миграционный взаимообмен между тувинцами Тувы и Усинского района. Но при этом усинские тувинцы всегда имели этнокультурную специфику, которая формировалась фактом их проживания за пределами национального государственного образования и тесным взаимодействием с русским населением. Современная история усинских тувинцев является логическим отражением и логическим продолжением многовековой истории тувинцев в Усинском районе. Поэтому, мы полагаем, что для всестороннего изучения данной этнической группы тувинцев необходима комплексная научно-исследовательская программа.

\section{СПИСОК ЛИТЕРАТУРЫ}

Krivonogov, V. P., Mikhailova Ya. S. (2015) The Usinsk Tuvans in the XXI century // Жypнал Сибирского федерального университета. Серия «Гуманитарные науки». Т. 8, № 4, Апрель. С. 793-804.

Messerschmidt, D. G. (1962) Forschungsreise durch Sibirien 1720-1727. - T. 1 : Tagebuchaufzeichnungen, 1721-1722 / Herausgegeben von E. Winter und N.A. Figurovskij; mit einem vorwort von W. Steinitz und A.V. Topčiev. Berlin : Akademie-Verlag. $380 \mathrm{~s}$.

Африканов, А. М. (1890) Русская торговля в Урянхайской земле // Известия ВСО ИРГО T. XXI. № 5. C. 1-33. 
Баранов, А. (1913) Урянхайский вопрос. Харбин : Типо-лит. Заамурскаго Округа Отд. Корп. Погр. Стр. 50 с.

Вся Сибирь, со включением Уральской области : справочная и адресная книга на 1925/26 г. : с приложением карты Азиатской части СССР и планами городов : НовоНиколаевска, Омска, Томска, Барнаула, Красноярска, Иркутска, Читы, Благовещенска, Владивостока и Свердловска (1925). М. : Издание «Известий ЦИК СССР». 606 с.

Дацышен, В. Г. (2009) Тувинское население Усинского пограничного округа Енисейской губернии. Из истории русско-тувинских отношений [Электронный ресурс] // Новые исследования Тувы. № 3. URL: https:/nit.tuva.asia/nit/article/view/634 (дата обращения: 12.12.2016).

Енисейские Епархиальные Ведомости (1884). № 1.

Журавель, Т. Н. (2011а) Сферы функционирования тувинского языка в Усинской котловине Красноярского края // Миноритарные языки в поликультурном пространстве России материалы Всероссийского научного семинара с международным участием, 29 июня 2011 г., Абакан / от. ред. Т. Г. Боргоякова. Абакан: Изд-во ХГУ им. Н. Ф. Катанова. 99 c. C. $16-19$.

Журавель, Т. Н. (2011b) Образ этнической родины в языковом сознании тувинцев Усинской котловины [Электронный ресурс] // Конференция «Молодёжь и наука 2011». Сибирский федеральный университет. URL: http:/conf.sfu-kras.ru/sites/mn2011/thesis/ s16/s16_12.pdf (дата обращения: 12.12.2016).

История Тувы (2007) / ред. В. А. Ламин. Новосибирск : Наука. Т. II. 430 с.

Кайский, М. (1926) Урянхайский вопрос // Северная Азия. Кн. 4. С. 16-25.

Касьянов Василий Дмитриевич, протоиерей (2012). Из дневников 1870-1897 гг. : в 2 кн. / автор-сост. А. В. Броднева. Красноярск : ООО Издательский дом «Восточная Сибирь». Кн. 1. 701 с.

Кон, Ф. Я. (1914) Усинский край // Записки Красноярского подъотдела ВосточноСибирского отдела Императорского Русского географического общества. Записки по географии. Т. II, вып. І. Красноярск : тип. б. М. И. Абалакова. 111 с.

Кривоногов, В. П., Михайлова, Я. С. (2014) Современная этнография усинских тувинцев // Родина. № 7. С. 91-96.

Куулар, Е. М. (2016) Некоторые особенности речи усинских тувинцев красноярского края // Казанская наука. № 9. С. 58-61.

Куулар, Е. М., Суванди, Н. Д. (2016) Языковая картина мира усинских тувинцев: этнолингвистический аспект // Филологические наук. Вопросы теории и практики. № 11-2. C. $112-115$.

Лавров К. П. (1920) Историческій очеркъ Саянскаго промыслово-охотничьяго района // Саянский промыслово-охотничий район и соболиный промысел в нем. Труды экспедиций по изучению соболя и исследованию соболиного промысла. Серия II. Саянская экспедиция. П. : Государственное издательство. 458 с. С. 17-58. 
Ламажаa, Ч. К. (2011) Тува между прошлым и будущим. 2-е изд.. испр. и доп. СПб. : Алетейя. 368 с.

Ламажаа, Ч. К. (2013) Тувиноведение: Новые горизонты. М. : Книжный дом «ЛиброКOM». $184 \mathrm{c}$.

Маннай-оол, М. Х. (1995) Тувинцы Монголии: традиции и современность // Ученые записки ТНИИЯЛИ. Серия историческая. Вып. XVIII. Кызыл : Тувинское книжное издательство. С. 56-61.

Михайлова, Я. С. (2014) Современные языковые процессы у усинских тувинцев [Электронный ресурс] // Новые исследования Тувы. № 2. URL: https://nit.tuva.asia/nit/article/ view/164 (дата обращения: 13.12.2016).

Моллеров, Н. М. (2005) История советско-тувинских отношений (1917-1944 гг.). М.: Институт молодежи. 326 с.

Монгуш, М. В. (2010) Один народ: три судьбы. Тувинцы России, Монголии и Китая в сравнительном контексте. Осака : Национальный Музей Этнологии. 358 с.

Отчет Красноярского Епархиального Комитета Православного Миссионерского Общества за 1901 г. (1902) // Енисейские Епархиальные ведомости. Красноярск. № 7. C.210.

Путилов, Н. (1914) Летопись Усинской миссии, находящейся на реке Усу, Енисейской губ. Минусинского округа, Шушенской волости, близ Китайской границы // Сибирский Архив. № 1. С. 27-40; № 3-4. С. 91-106, № 5.

Русско-китайские отношения в XVIII веке. Документы и материалы. T. III: Русскокитайские отношения. 1727-1729 (2006) / отв. ред. С. Л. Тихвинский. М. : Памятники исторической мысли. 544 с.

Русско-монгольские отношения. 1654-1685. Сборник документов (1996) / сост. Г.И.Слесарчук. М. : Восточная литература. 560 с.

Собрание архивных документов о протекторате России над Урянхайским краем Тувой : к 100-летию исторического события (2014) / сост.: Бондаренко Т. А. и др. Кызыл : ТИГИ. 479 с.

Сойоты // Объяснительная записка к этнографической карте Сибири (1929) / ред. С.Ф.Ольденбург, С. И. Руденко. Л. : Изд-во Академии наук. 104 с. С. 60-61.

Соян, А. М. (2016) Песни и частушки усинских тувинцев // Мир науки, культуры, образования. Т. 61, № 6. С. 371-373.

Степанов, А. П. (1997) Енисейская губерния. Красноярск : Горница. 223 с.

Сувандии, Н. Д. (2016) Особенности собственных имен усинских тувинцев // Филологические науки: вопросы теории и практики. № 12-1(66). С. 163-165.

Риттер, К. (2007) Землеведение Азии. Том III // Урянхай. Тыва дептер: антология научной и просветительской мысли о древней тувинской земле и ее насельниках, об Урянхае - Тану-Туве, урянхайцах - тувинцах, о древностях Тувы / сост. С. К. Шойгу. М. : Слово/ Slovo. T. 2. Племена Саяно-Алтая. Урянхайцы (IV - начало XX в.). 664 с. С. 110-187. 
Родевич, В. Очерк Урянхайского края // Урянхай. Тыва дептер: антология научной и просветительской мысли о древней тувинской земле и ее насельниках, об Урянхае - тану-Туве, урянхайцах - тувинцах, о древностях Тувы / сост. С. К. Шойгу. М. : Слово/ Slovo. T. 3: Урянхайский край. Тувинско-русские отношения (начало XVII - начало XX вв.). 608 с. С. $344-541$.

Шварц, Л. Э. (2007) Подробный отчет о результатах исследований математического отдела Сибирской экспедиции Императорского Русского Географического общества (извлечения) // Урянхай. Тыва дептер: антология научной и просветительской мысли о древней тувинской земле и ее насельниках, об Урянхае - Тану-Туве, урянхайцах - тувинцах, о древностях Тувы / сост. С. К. Шойгу. М. : Слово/Slovo. Т. 5: Урянхайский край. Урянхайский край: от Урянхая к Танну-Туве (конец XIX - первая половина XX вв.). 736 c. С. 34-75.

Фельде, О. В., Журавель, Т. Н. (2012) Тувинский язык в Красноярском крае. Опыт социопсихолингвистического исследования // Вестник Томского государственного педагогического университета. № 10 (125). С.159-163.

Дата поступления: 12.07.2016 г.

\section{REFERENCES}

Krivonogov, V. P. and Mikhailova Ya. S. (2015) The Usinsk Tuvans in the XXI century. Zhurnal Sibirskogo federal'nogo universiteta. Seriia «Gumanitarnye nauki», vol. 8, no. 4, April, pp. 793-804.

Messerschmidt, D. G. (1962) Forschungsreise durch Sibirien 1720-1727. Vol. 1: Tagebuchaufzeichnungen, 1721-1722 / Herausgegeben von E. Winter und N.A. Figurovskij; mit einem vorwort von W. Steinitz und A.V. Topčiev. Berlin, Akademie-Verlag. 380 s. (In Germ.).

Afrikanov, A. M. (1890) Russkaia torgovlia v Uriankhaiskoi zemle. Izvestiia VSO IRGO, vol. XXI, no. 5, pp. 1-33. (In Russ.).

Baranov, A. (1913) Uriankhaiskii vopros. Kharbin, Tipo-lit. Zaamurskago Okruga Otd. Korp. Pogr. Str. 50 p. (In Russ.).

Vsia Sibir', so vkliucheniem Ural'skoi oblasti : spravochnaia i adresnaia kniga na 1925/26 g.: s prilozheniem karty Aziatskoi chasti SSSR i planami gorodov : Novo-Nikolaevska, Omska, Tomska, Barnaula, Krasnoiarska, Irkutska, Chity, Blagoveshchenska, Vladivostoka i Sverdlovska (1925). Moscow, Izdanie «Izvestii TsIK SSSR». 606 p. (In Russ.).

Datsyshen, V. G. (2009) The Tuvan population of Usinsk boundary district of the Yenisei province. From the history of relations between Russia and Tuva. Novye issledovaniia Tuvy, no. 3 [online] Available at: https://nit.tuva.asia/nit/article/view/634 (access data: 12.12.2016). (In Russ.).

Eniseiskie Eparkhial'nye Vedomosti (1884). № 1. (In Russ.).

Zhuravel', T. N. (2011a) Sfery funktsionirovaniia tuvinskogo iazyka v Usinskoi kotlovine Krasnoiarskogo kraia. In: Minoritarnye iazyki v polikul'turnom prostranstve Rossii materialy 
Vserossiiskogo nauchnogo seminara s mezhdunarodnym uchastiem, 29 iiunia 2011 g., Abakan, ed. T. G. Borgoiakova. Abakan, Izd-vo KhGU im. N. F. Katanova. 99 p. Pp. 16-19. (In Russ.)

Zhuravel', T. N. (2011b) Obraz etnicheskoi rodiny v iazykovom soznanii tuvintsev Usinskoi kotloviny. Konferentsiia «Molodezh' i nauka 2011». Sibirskii federal'nyi universitet [online] Available at: http://conf.sfu-kras.ru/sites/mn2011/thesis/s16/s16_12.pdf (access date: 12.12.2016). (In Russ.)

Istoriia Tuvy (2007), ed. V. A. Lamin. Novosibirsk, Nauka. Vol. II. 430 p. (In Russ.)

Kaiskii, M. (1926) Uriankhaiskii vopros. Severnaia Aziia, book 4, pp. 16-25. (In Russ.)

Kas'ianov Vasilii Dmitrievich, protoierei (2012). Iz dnevnikov 1870-1897 gg. : in 2 books, comp. A. V. Brodneva. Krasnoiarsk, OOO Izdatel'skii dom «Vostochnaia Sibir'». Book 1. 701 p. (In Russ.)

Kon, F. Ya. (1914) Usinskii krai. In: Zapiski Krasnoiarskogo pod»otdela Vostochno-Sibirskogo otdela Imperatorskogo Russkogo geograficheskogo obshchestva. Zapiski po geografii, vol. II, issue I. Krasnoiarsk, tip. b. M. I. Abalakova. 111 p. (In Russ.)

Krivonogov, V. P. and Mikhailova, Ia. S. (2014) Sovremennaia etnografiia usinskikh tuvintsev. Rodina, no. 7, pp. 91-96. (In Russ.)

Kuular, E. M. (2016) Nekotorye osobennosti rechi usinskikh tuvintsev krasnoiarskogo kraia. Kazanskaia nauka, no. 9, pp. 58-61. (In Russ.)

Kuular, E. M. and Suvandi, N. D. (2016) Iazykovaia kartina mira usinskikh tuvintsev: etnolingvisticheskii aspect. Filologicheskie nauk. Voprosy teorii i praktiki, no. 11-2, pp. 112115. (In Russ.)

Lavrov K. P. (1920) Istoricheskii ocherk Saianskago promyslovo-okhotnich'iago raiona. In: Saianskii promyslovo-okhotnichii raion $i$ sobolinyi promysel $v$ nem. Trudy ekspeditsii po izucheniiu sobolia $i$ issledovaniiu sobolinogo promysla. Seriia II. Saianskaia ekspeditsiia. Petrograd, Gosudarstvennoe izdatel'stvo. 458 p. pp. 17-58. (In Russ.)

Lamazhaa, Ch. K. (2011) Tuva mezhdu proshlym i budushchim. 2nd ed. St. Petersburg, Aleteiia. 368 p. (In Russ.)

Lamazhaa, Ch. K. (2013) Tuvinovedenie: Novye gorizonty. Moscow, Knizhnyi dom «Librokom». 184 p. (In Russ.)

Mannai-ool, M. Kh. (1995) Tuvintsy Mongolii: traditsii i sovremennost'. In: Uchenye zapiski TNIIIaLI. Seriia istoricheskaia. Vol. XVIII. Kyzyl, Tuvinskoe knizhnoe izdatel'stvo. Pp. 56-61. (In Russ.)

Mikhailova, Ya. S. (2014) Modern lingual processes among Tuvans of Usinsk. Novye issledovaniia Tuvy, no. 2 [online] Available at: https://nit.tuva.asia/nit/article/view/164 (access date: 13.12.2016). (In Russ.)

Mollerov, N. M. (2005) Istoriia sovetsko-tuvinskikh otnoshenii (1917-1944 gg.). Moscow, Institut molodezhi. 326 p. (In Russ.)

Mongush,M.V.(2010) Odin narod: tri sud'by. Tuvintsy Rossii, Mongolii i Kitaia v sravnitel'nom kontekste. Osaka, Natsional'nyi Muzei Etnologii. 358 p. (In Russ.) 
Otchet Krasnoiarskogo Eparkhial'nogo Komiteta Pravoslavnogo Missionerskogo Obshchestva za 1901 g. (1902). Eniseiskie Eparkhial'nye vedomosti (Krasnoiarsk), no. 7, pp. 210. (In Russ.)

Putilov, N. (1914) Letopis' Usinskoi missii, nakhodiashcheisia na reke Usu, Eniseiskoi gub. Minusinskogo okruga, Shushenskoi volosti, bliz Kitaiskoi granitsy. Sibirskii Arkhiv, no. 1, pp. 27-40; no. 3-4, pp. 91-106, no. 5. (In Russ.)

Russko-kitaiskie otnosheniia v XVIII veke. Dokumenty i materialy. Vol. III: Russko-kitaiskie otnosheniia. 1727-1729 (2006), ed. S. L. Tikhvinskii. Moscow, Pamiatniki istoricheskoi mysli. 544 p. (In Russ.)

Russko-mongol'skie otnosheniia. 1654-1685. Sbornik dokumentov (1996), comp. G.I.Slesarchuk. Moscow, Vostochnaia literatura. 560 p. (In Russ.)

Sobranie arkhivnykh dokumentov o protektorate Rossii nad Uriankhaiskim kraem - Tuvoi : $k$ 100-letiiu istoricheskogo sobytiia (2014), comp. T. A. Bondarenko et al. Kyzyl, TIGI. 479 p. (In Russ.)

Soioty. In: Ob'iasnitel'naia zapiska k etnograficheskoi karte Sibiri (1929), ed. S. F. Ol'denburg and S. I. Rudenko. Leningrad, Izd-vo Akademii nauk. 104 p. Pp. 60-61. (In Russ.)

Soian, A. M. (2016) Pesni i chastushki usinskikh tuvintsev. Mir nauki, kul'tury, obrazovaniia, vol. 61, no. 6, pp. 371-373. (In Russ.)

Stepanov, A. P. (1997) Eniseiskaia guberniia. Krasnoiarsk, Gornitsa. 223 p. (In Russ.)

Suvandii, N.D. (2016) Osobennosti sobstvennykh imen usinskikh tuvintsev. Filologicheskie nauki: voprosy teorii i praktiki, no. 12-1 (66), pp. 163-165. (In Russ.)

Ritter, K. (2007) Zemlevedenie Azii. Tom III. In: Uriankhai. Tyva depter: antologiia nauchnoi i prosvetitel'skoi mysli o drevnei tuvinskoi zemle i ee nasel'nikakh, ob Uriankhae - Tanu-Tuve, uriankhaitsakh - tuvintsakh, o drevnostiakh Tuvy, comp. S. K. Shoigu. Moscow, Slovo/Slovo. Vol. 2. Plemena Saiano-Altaia. Uriankhaitsy (IV - nachalo XX v.). 664 p. Pp. 110-187. (In Russ.)

Rodevich, V. Ocherk Uriankhaiskogo kraia. In: Uriankhai. Tyva depter: antologiia nauchnoi i prosvetitel'skoi mysli o drevnei tuvinskoi zemle i ee nasel'nikakh, ob Uriankhae - Tanu-Tuve, uriankhaitsakh - tuvintsakh, o drevnostiakh Tuvy, comp. S. K. Shoigu. Moscow, Slovo/Slovo. Vol. 3: Uriankhaiskii krai. Tuvinsko-russkie otnosheniia (nachalo XVII - nachalo XX vV.). 608 p. Pp. 344-541. (In Russ.)

Shvarts, L. E. (2007) Podrobnyi otchet o rezul'tatakh issledovanii matematicheskogo otdela Sibirskoi ekspeditsii Imperatorskogo Russkogo Geograficheskogo obshchestva (izvlecheniia). In: Uriankhai. Tyva depter: antologiia nauchnoi i prosvetitel'skoi mysli o drevnei tuvinskoi zemle i ee nasel'nikakh, ob Uriankhae - Tanu-Tuve, uriankhaitsakh - tuvintsakh, o drevnostiakh Tuvy, comp. S. K. Shoigu. Moscow, Slovo/Slovo. Vol. 5: Uriankhaiskii krai. Uriankhaiskii krai: ot Uriankhaia k Tannu-Tuve (konets XIX - pervaia polovina XX vV.). 736 p. Pp. 34-75. (In Russ.) 
Fel'de, O. V. and Zhuravel', T. N. (2012) Tuvinskii iazyk v Krasnoiarskom krae. Opyt sotsiopsikholingvisticheskogo issledovaniia. Vestnik Tomskogo gosudarstvennogo pedagogicheskogo universiteta, no. 10 (125), Pp. 159-163. (In Russ.)

Submission date: 17.07.2016.

\section{Для циттиования:}

Дацышен В. Г. Особенности истории усинских тувинцев [Электронный ресурс] // Новые исследования Тувы. 2017. № 1. URL: https://nit.tuva.asia/nit/article/view/694 (дата обращения: дд.мм.гг.). DOI: 10.25178/nit.2017.1.2

\section{For citation:}

Datsyshen V. G. Aspects of history of the Usinsk Tuvans. New Research of Tuva. 2007, no.1 [online] Available at: https://nit.tuva.asia/nit/article/view/694 (access date: dd.mm.yy.). DOI: $10.25178 /$ nit.2017.1.2 